\title{
Liberal Reforms and Community Responses in Mexico ${ }^{1}$
}

\author{
by \\ Alain de Janvry, Céline Dutilly, Carlos Muñoz-Piña, and Elisabeth Sadoulet \\ University of California at Berkeley
}

\section{From state-led to community-led governance}

\subsection{The ejido before the 1992 reforms}

Rural communities have, in Mexico, an extraordinarily important, and yet largely unrecognized, role in influencing the way in which a huge endowment of natural resources is used and local public goods are delivered to a majority of the rural population. By contrast to Africa and North East Asia (Hayami and Platteau, 1998), these communities generally do not have their roots in tribal or ancestral village origins. They are instead mostly creation of the state, product of the political settlement that followed 10 years of peasant-led armed revolution. This settlement led to formation of the ejido communities as defined in the constitution of 1917. In some cases, land that had been expropriated from indigenous communities by expansion of the haciendas was restituted, giving a tribal basis to the ejido communities. But in the vast majority of cases, communities were created by pulling together in ejidos the former workers of expropriated haciendas or ad-hoc groups of rural households demanding access to land. A dual form of property rights was thus created, covering today each approximately half of the Mexican territory. On the one hand, a sector of private farms with a ceiling on land ownership equivalent to 100 hectares of irrigated land (the "pequeñas propriedades"). On the other hand, a social sector, generically referred to as the ejido sector, that includes indigenous communities with restituted lands and new ejido communities created by the reform, with ejido communities outnumbering indigenous communities 15 to 1 . In this ejido sector, all land is owned by the community. Land in ejidos is also accessed under a dual system of land rights: individual plots to which ejidatario households have access in usufruct; and common property resources (CPR) to which all ejidatarios have access as regulated by the community.

To understand how the ejido community was organized to manage its affairs, it is important to relate this to the purposes of the 1917 reforms (Gordillo, de Janvry, and Sadoulet, 1998). Because the land reform occurred as the outcome of a peasant-led revolution that left one million dead, creation of the ejido sector had both political and economic objectives that would eventually run at cross purposes. The political objective was to contain peasant demands within the institutionalized political process and to incorporate them as clients of the ruling political party. This was done by using corporatist organizations, such as the National Confederation of Peasants (CNC), itself a part of the ruling political party, to mediate the relation between peasants and the state. The state thus had a strong pro-active role in managing the political life of the community. The economic objective was to organize production more efficiently than in the hacienda, particularly for the delivery of staple foods to the urban sector while the private sector was specializing in high value crops. Land reform beneficiaries were, however, considered unable to manage their own economic affairs, and they were thus placed, like infants, under the tutelage of the state. This applied not only to the delivery of public goods in the community and the management of common property resources, but also to production in individual plots. On those, access to the market and to essential services such as credit and insurance was mediated by community leadership, itself under strong control of the state. While tutelage could have been a rapid transition toward independent management of community affairs, submission to state control was maintained over the years and it took waiting until the liberal reforms of 1992 for this to happen. To achieve both political and economic objectives, the communities were thus placed under strong control of the state.

\footnotetext{
1 Chapter 12 in Aoki, M. and Y. Hayami (eds) Communities and Markets in Economic Development, Oxford University Press, 2001
} 
Governance in ejidos was organized through three internal bodies that reflected this main mise of the state (Baitennmann, 1998).

1. The general assembly. This was the highest authority in the ejido, constituted of all official members (ejidatarios) in the ejido. Meetings were to be held not less than once a month, with decisions taken on a majority vote. Decisions concerned internal rules and regulations of the ejido, election of the members of the other two internal bodies, authorization and regulation of production and marketing decisions, resolution of disputes, and changes in ejido membership and land allocation. Whenever issues of access to land or production were to be discussed, a representative of the Secretariat of Agrarian Reform (SRA) had to be present.

2. The executive board, composed of six elected members under the leadership of a president. While elected by the assembly, this president could exercise considerable influence over ejido affairs. Because of the importance of political clientelism in accessing public goods and services, the president of the executive board also had close linkages with the ruling political party.

3. The oversight council, also with six elected members, in charge of providing checks and balances in the performance of the assembly and the executive board.

Not only was the state thus importantly present in the internal management of community affairs, SRA regulations additionally severely constrained what communities and ejidatarios were allowed to do. For instance, ejidatarios had to work their lands directly as they were not allowed to hire wage labor. They could not rent the land or sell it. Absences from the ejido for more than two years led to loss of the right to land. Ejidatarios could not transfer their land plots to more than one heir to prevent atomization of the land. ${ }^{2}$ The state was also involved in ejido arbitration matters since family controversies and boundary conflicts with other ejidos or private farms had to be settled in administrative tribunals under the authority of the SRA. Access to credit was obtained from the state agricultural bank through the ejido, not individually, with all ejidatarios co-liable for the total amount of credit received. Credit was granted for specific crops with specific agronomic practices, leaving little leeway for individual initiatives. Marketing of staple crops was through the parastatal CONASUPO that made payments of ejidatario debts directly to the state agricultural bank. Parastatals were also mediating institutions for access to inputs and sale of specialized crops such as coffee, cocoa, sugar cane, and tropical fruits. All borrowers from the official bank were required to purchase crop insurance from a single government insurance agency.

Mechanisms of evasion were of course plentiful, from lack of participation to assemblies, to corruption, and to the development of active secondary markets for basically all factors and services controlled by state intervention. For instance, land was commonly rented and sometimes sold through informal arrangements to other community members and sometimes to outsiders. Wage labor was hired to replace family members who had migrated. Assemblies were often held without a representative of the state and minutes falsified to claim that the official had been present. The names of ejidatarios who had left would continue to appear on the list of participants to assemblies so they would not lose their rights. Secondary markets and illegal practices were thus important in adapting the highly regulated management of community affairs and individual income strategies to the desires of community members. Efficiency and equity costs were of course enormous, but they allowed gains compared to strict implementation of the law.

Thus, while land legally belonged to the community and its management was under the jurisdiction of the community, the state had strong control over community affairs. Community cooperation was a state regulated more than a voluntaristic act. In spite of secondary markets and corruption, the ejido sector had become a truncated peasant economy and peasant community in the grips of a model of political and social control (de Janvry, Gordillo, and Sadoulet, 1997).

2 This was not the case in indigenous communities were community membership by birth gave right of access to land to all members, including the many descendants of any original member. 


\subsection{The ejido since the 1992 reforms}

While the ejido sector showed strong production performance through the 1960s, principally based on extensive programs of public investment in large scale irrigation projects, multiple state-imposed constraints on community and individual initiatives gradually brought production to stagnation and welfare to poverty. In addition, democratic opening eroded the ruling party's monopolistic control over the ejido and undermined effectiveness of the ejido as an instrument of political control. The costs of economic stagnation and extensive public subsidies could no longer be justified by political gains for the ruling party. There were also strong pressures from urban and business interests to gain access to ejido lands through an open land market. In a general context of structural adjustment reforms pursuing economic liberalization, the constitution of 1917 was amended in 1992 to allow privatization of individual plots (with associated greater security of tenure and possibility of using land as collateral for credit), freedom of managing individual and community land as seen fit, and the right for individuals or the whole community to associate with private interests outside the ejido in pursuit of business advantages.

The reforms were expected to change drastically the structure of governance in the ejido, promoting community-led as opposed to state-led management. The role of the president of the executive board was to decline while democratic representation was to increase through greater power attributed to the assembly. The president could only be elected to a three years term without renewal and his/her duties were to become largely administrative. The assembly, however, also lost importance with individualization of decision-making over land transactions, land use, marketing decisions, and access to supporting services such as technical assistance and credit. For instance, after certification of land rights to individual ejidatarios under PROCEDE (the Program to Certify Ejidatario Rights and Land Plots), land transactions no longer need authorization from the assembly, but only signature from two witnesses and notification to the National Land Registry (RAN). Disputes among ejidatarios can be settled directly with the Office of the Agrarian Attorney General (Procuradoria Agraria) without referral to the assembly. And assemblies are only required to meet once every six months instead of monthly.

By severely diminishing restrictions on individual behavior and the role of the state in ejido affairs, the reforms can thus have a contradictory impact on the role of the community and the determinants of cooperation. Where cooperation is deemed worthwhile by ejidatarios and they have the ability to cooperate, the role of the community could be enhanced, evolving from mandatory cooperation to voluntary (endogenous) cooperation. For the delivery of public goods, collective arrangements in support of production (e.g., for accessing credit and technical assistance or reducing transactions costs in participating to markets), and the management of common property resources, cooperation may thus become more effective. By contrast, where cooperation is deemed a cost more than a benefit, or where structural conditions are unfavorable to cooperation, the role of the community may instead wane. The reforms in themselves thus do not guarantee a greater cooperative outcome. Laws codifying the relative roles of the assembly and the executive board are unenforceable by SRA and unable to per-se curtail the power of local bosses. Laws codifying decision-making processes within the ejido are also inadequate to guarantee democratic behavior. For instance, secret ballots are not required and show of hands are still the norm, facilitating coercion by ejido bosses.

Under the reforms, ejidatarios have the options of: (1) Obtaining certificates of land ownership that allow them to rent land and sell it internally to the community. These certificates are granted by the PROCEDE program and participation of an ejido to this program requires majority approval in the assembly. (2) Obtaining full titles over their certified land plots, allowing them to additionally sell land to outsiders. Full titling is costly and requires a two-thirds majority approval in the assembly. (3) Dissolving the ejido as a community organization with economic, political, and social purposes. In the process of certification, ejidatarios also have the power to appropriate common property resources in individual ownership if this is ratified by the assembly, unless these lands are designated as protected for environmental purposes. Appropriating common property resources in individual ownership allows members to expand their individual land plots and/or to incorporate new members in the ejido. If the ejido were dissolved, common property resources would return to the state. Observations show that certification has progressed rapidly, with some $75 \%$ of the ejidos either completed or in progress. Titling has, by contrast, been practically non-existent, indicating that ejidatarios are concerned in preserving the ejido 
community, at the cost of restricting land transactions with outsiders. Based on case studies, Goldring (1998) observes that ejidatarios value the ejido as an organization for its support in production, access to common property resources, as a source of social and political capital, and to give them a sense of community identity that they feel is worth preserving. Hence, the issue of the role of the community and of the ability of the community of cooperating in managing its resources and its affairs is not made mute by the reforms. There is, however, no longer any guarantee that the level of cooperation achieved will be, at a minimum, as mandated by the state. Cooperation is now endogenous to community determination. In some cases, cooperation may thus wane and in others it may be consolidated by the need and opportunity of assuming leadership over community affairs without state tutelage. It is this issue of community response to economic and political liberalization, and in particular of adjusting cooperative practices and of preserving or dividing common property resources, that we address in this paper.

\section{The ejido sector today}

Today, the ejido sector (including both new ejidos created by the land reform and lands restituted to indigenous communities) is composed of 28,058 communities with 3.5 million ejidatario households, 18 million individuals, and some $70 \%$ of the rural population. It is consequently a very important sector in terms of population, control over natural resources, share of agricultural production, and also incidence of poverty.

The data we use here to characterize the ejido are based on two nation-wide surveys of the ejido sector. The 1994 survey was done by the SRA and the University of California at Berkeley (see de Janvry, Gordillo, and Sadoulet, 1997); the 1997 survey was done by the SRA and the World Bank (see Louise Cord and others, 1998). The surveys are panels of ejidos and ejidatario households that include 286 ejidos and 1634 ejidatario households. The 1994 survey occurred before the PROCEDE program was initiated and largely before the communities had adjusted management practices, while the 1997 survey was done after much adjustment had already happened.

We describe the ejido in terms of importance of individual plots and CPR, quality of governance, provision of public goods, use of CPR, and quality of cooperation using the 1997 data. Table 1 shows that CPR are important since they account for $69.9 \%$ of the total land in ejidos, while individual plots in usufruct account for $28.4 \%$. Not all ejidos have CPR: as can be seen in Table 2, 21\% do not have any. Among the $79 \%$ that do, individual plots per member cover 11.3 hectares and CPR per member 35.2 hectares (Table 1). For some ejidos with extensive grazing and forest areas, CPR cover the majority of the territory: thus $47.2 \%$ of the ejidos have more than half their total territory in CPR (Table 2).

Table 3 shows that the two most important uses of CPR are pastures and forests: $77.6 \%$ of all ejidos have CPR pastures that account for $51.6 \%$ of all ejido land; $50.2 \%$ of all ejidos have forested land and it covers $36.5 \%$ of all ejido land. Land in CPR is also used for individual cultivation of crops since these lands can be allocated by the Assembly to individual households, including non-ejidatario residents of the ejido. Table 3 shows that $25.6 \%$ of the ejidos have some land used in this fashion, but this only occupies $5.6 \%$ of total ejido land. Finally, $5.8 \%$ of the ejidos have collective farming activities in CPR, usually special women and youth projects, or collective projects to generate resources in support of social activities. They occupy a minute $0.3 \%$ of the land.

Use of CPR lands for individual cultivation, and eventual appropriation of CPR land in individual ownership under PROCEDE, are importantly affected by population pressure over the land. This pressure originates in the fact that ejidatarios were not legally allowed to divide their plots among heirs. The child or spouse who inherited the usufruct right to the plot of land thus became the replacement ejidatario. Children other than the one who officially inherited the land either had to migrate or stayed in the ejido as posesionarios (individuals with access to a plot of land in the ejido, but no right to vote in the Assembly or to use the CPR) or as avencidados (individuals who live in the urban area of the ejido where they may have usufruct or ownership of an urban lot but no access to ejido land and no voting rights). Since more than half of the ejidos have been created before 1940, non-ejidatario households that reside in the ejido have become numerous in site of occasional permission granted by SRA to incorporate new members. These 
two categories of non-members eventually represent large groups, usually kinship related to ejidatarios, with much desire to gain access to land in the ejido and to official rights of participating to ejido affairs.

Overall, landless avencidados are very important, representing $29.7 \%$ of the ejido population, and casually landed posesionarios represent $10.5 \%$ of the ejido population, while ejidatarios as a consequence only represent $59.9 \%$ (Table 4). Hence, population pressure to access land and become official ejido members is high. In ejidos with avencidados, these households match ejidatarios one to one. In ejidos with posesionarios, there are four posesionario households for every ten ejidatarios.

The quality of governance and cooperation in managing ejido affairs are characterized in Table 5. One can see that quality of governance and cooperation are, overall, weak: $46 \%$ of the ejidos do not have internal rules, $27 \%$ of the ejidos fail to achieve a quorum at the first call of an assembly, and $35 \%$ of the ejidatarios do not participate to assemblies.

Cooperation applies to the provision of services to maintain or improve CPR, to the extraction of resources in grazing and forestry, and to the provision of local public goods. Here again, we see that rules to increase provision and limit extraction are uneven and overall weak. It is only to the provision of local public goods that significant percentages of participation are observed. For instance, $63 \%$ of the ejidatarios participate to road repair activities and $57 \%$ to school maintenance. However, even vital public services such as maintenance of irrigation infrastructure are weakly attended.

\section{Liberal reforms and changes in community cooperation}

With the advent of the reforms, the determinants of cooperation should become increasingly endogenous to the community, i.e., explained by the characteristics of the community and its environment. However, there was plenty of opportunity to bend the rules of state-mandated cooperation before the reforms. Peasant communities are indeed notable for foot dragging (Scott, 1976) and we have seen that there was extensive bending of the rules and failing to comply with state-defined cooperative practices. Hence, much adjustment of cooperation to community and contextual characteristics may have already occurred before the reforms. In this section, we assess what are the determinants of cooperation across communities, and how much of a change in cooperation can be attributed to the reforms, with some ejidos increasing cooperation in response to endogenous incentives while others decreased cooperation as state impositions were removed.

There are several symptoms of cooperation that we observe in the two periods: the frequency of assembly meetings, whether a quorum is achieved when an assembly is first called, the percentage of members assisting assemblies, and whether the ejido has formal internal rules in compliance with SRA requirements. From the standpoint of endogenous cooperative behavior, the most meaningful indicator is the percentage of ejidatarios that participate to assemblies since this is a clearly voluntaristic act as opposed to an administrative decision (number of meetings, internal rules).

Data on assistance to assemblies suggest considerable heterogeneity in levels of cooperation across ejidos. In $1997,23 \%$ of the ejidos had less than $50 \%$ of their members attending assemblies, $45 \%$ between $50 \%$ and $80 \%$ attendance, and $32 \%$ above $80 \%$ attendance. Assistance to assemblies, remained essentially constant over the period, with an average of $66 \%$ in 1994 and $69 \%$ in 1997 . However, there were many changes across ejidos:

$37 \%$ of the ejidos kept roughly the same attendance (a change of $+/-10 \%$ in participation)

$29 \%$ of the ejidos increased attendance (more than $10 \%$ increase in participation)

$34 \%$ of the ejidos decreased attendance (more than $10 \%$ decrease in participation).

These data thus indicate that there are different degrees of cooperation across communities. How can this be explained? In the literature (Ostrom, 1992; Baland and Platteau, 1996), cooperation has been looked at as a binary matter: either the expected gains from cooperating exceed the fixed costs of cooperation, and cooperation occurs; or expected gains do not cover costs and there is cooperation failure. If, instead of 
binary levels of cooperation, we observe a continuum in degrees of cooperation, this suggests that other explanations are necessary. A possible explanation is as follows.

For an ejido community, the expected gains from cooperation are a function of the quantity and quality of the resource to be collectively used. The community thus makes an effort to induce members to cooperate, including attendance at assembly meetings, that is proportional to the quantity and quality of the resources it controls. The level of this effort depends on the expected gains from cooperation and on the costs of enforcing cooperation which are function of a set of characteristics of the ejido. For an individual community member, the cost of cheating on attendance is the disutility created by failing to attend meetings that results in ostracization of the member and loss of social capital in the community, with the attendant negative consequences for access to mutual insurance, information, employment, etc. through other community members. This disutility varies across individual members. Good citizens and poorer members take it very seriously, while opportunists and richer members do not attach as much importance to it. This schedule is represented by UU in Figure 1, with community members ranked by decreasing order of importance they attach to community pressure to conform. For a community member, the cost of participating in the assemblies is the opportunity cost of time measured in utility. Across community members, this disutility schedule is represented by the downward sloping curve cc in Figure 1. Even if the cost of attending meetings is the same for all members, the disutility of this cost should decline with the ranking of individuals according to decreasing importance they attach to community pressure to conform if both are associated with wealth.

Intersection of the UU and cc schedules, if it exists, implies that there is an equilibrium percentage of participants $n$ to assembly meetings. This equilibrium percentage increases with the expected benefits from cooperation and declines with the costs of enforcing cooperation. This gives us the following econometric specification of an equation explaining degree of participation to assembly meetings across ejidos:

Endogenous variable: percentage of members participating to assembly meetings.

Exogenous variables:

Expected benefits from cooperation

Quantity of the resource: hectares of CPR per ejidatario.

Effective price of resources extracted $=$ transactions costs to market $=$ distance to the nearest population center.

Variable costs (difficulties) of enforcing cooperation

Group size: number of ejidatarios, number of posesionarios and avecindados, group heterogeneity (disparity in plot sizes).

Availability of exit options: size of migration network.

Social cohesion: ejido with an indigenous majority, age of the ejido.

Degree of control over the resource: existence of external border conflicts.

Facilitators of enforcement: ejido has collective sources of income.

History of cooperative behavior: past symptoms of cooperation such as frequency of assembly meetings, frequency of achieving a quorum on first call of an assembly, assistance to assemblies, and existence of internal rules.

Results in Table 6 show that cooperation in 1994 was already quite well explained by the expected endogenous determinants of cooperation. Expected benefits from cooperation matter: both market integration (the negative of distance to market) and the quantity of CPR per ejidatario increase participation to assemblies. The variable costs of enforcing cooperation reduce participation: group size (the number of ejidatarios) creates a disincentive to participate. The number of non-members in the community (avecindados) also plays negatively as it undermines the quality of cooperation by increasing the number of potential cheaters. Group heterogeneity, measured by disparity in plot size, creates higher costs of monitoring and reduces participation. Social cohesion under the form of an homogenous ethnic population helps cooperation. And lack of control over external borders, that is whether the ejido is subjected to open access abuses, deters the effectiveness of cooperation and reduces incentives to participate to meetings. 
Three years is only a short time span for behavior to adjust to the new mode of cooperation implied by devolution. Hence, the levels of cooperation observed in ejidos cannot be expected to have reached a new equilibrium, making the levels of cooperation observed in 1997 difficult to explain. There are several variables that no longer affect cooperation. The role of expected benefits from cooperation was undermined in 1997 by a severe crisis of price incentives for the major staples produced by the ejido (Cord et al., 1998). Consequently, the differential levels of cooperation across ejidos should be found more on the cost side than on the side of expected benefits. The number of non-members in the ejido (avecindados) and existence of external border conflicts have been resolved by the reforms, making them less important as determinants of cooperation. By contrast, the total number of ejidatarios, now including the new members incorporated under the reforms (see next section), still plays a negative role. The size of the communities for effective cooperation thus remains a major issue. The exit option, represented by the size of the migration network to which members of an ejido have access (the percentage of adults with past migration experience in the ejido), is increasingly available to ejidatarios since the reforms offered greater freedoms to rent land and to allocate labor as pleased. As a consequence, we see that greater exit options now undermine cooperation, a regularity rationalized by Hirschman (1970). Other variables such as ethnicity remain positively related to cooperation, but have dropped in significance. We must carefully refrain from stating on the future role of these variables until a new cooperative equilibrium has been reached. We thus conclude that two powerful regularities dominate the effectiveness of cooperation under devolution: group size and exit options, both of which are detrimental to cooperation. More complete identification of the determinants of cooperation under the new rules will have to wait until a new equilibrium is reached.

We can explore further the role of the size of the community in affecting the quality of cooperation in 1997 by introducing a spline in the relation between assistance to assemblies and the number of ejidatarios. ${ }^{3}$ Seeking by tatonnement the optimum breaking points in the number of ejidatarios on a best fit basis, we locate those at community sizes of 50 and 75 (Table 7). Results are represented in Figure 2. We see that there is no impact of group size on the quality of cooperation when the ejido has less than 50 members since the slope is not significantly different from zero. There is then a significant precipitous drop in the quality of cooperation as membership exceeds 50 until it reaches 75 . In this range, the marginal effect of community size on assistance to assemblies is that for every 10 additional members, the percentage of members who assist to assemblies decreases by $8 \%$. In communities with more than 75 members, the quality of cooperation continues to deteriorate as group size increases. The marginal impact of group size declines to a drop in assistance to assemblies of only $0.7 \%$ for every additional 10 members, but this effect is still very significantly different from zero.

Seen from the angle of quality of cooperation, ejidos of size 50 or less would thus be optimum. If there are economies of scale in the provision of public goods, 50 would be preferred to a smaller number. Beyond this, there exists a tradeoff between moral hazards (quality of cooperation) and cost of delivery of public goods. Visits to ejidos in Michoacan (e.g., Paso del Muerto) led us to observe that 50 or less is indeed an effective size for organizing cooperation, with the optimum size affected by a number of idiosyncratic factors including existence of scale economies for the delivery of particular public goods in specific ejidos.

Since we have panel data, we can use the observed changes in cooperation between 1994 and 1997 to explain why cooperation improved in some ejidos while it declined in others. Results are presented in Table 8. Since non-zero changes in the explanatory variables over the period are endogenous, changes in cooperation are explained by the benefits and costs of cooperation in 1994, the specific purposes of cooperation during the transition period, and the ejidos' history of cooperative behavior as observed in 1994. Again, a full adjustment cannot be observed, but differences across ejidos are already notable. We see again that ejidos with larger membership and with greater exit options are the ones where the intensity of cooperation declined. Cooperative behavior in the transition was used to resolve community problems. We thus see that existence of external border conflicts induces a cooperative response now that ejidatarios

\footnotetext{
3 A spline regression fits a line with discontinuities in the slope at specific breaking points. The slope between breaking points is the cumulative value of the regression coefficients in that and all previous intervals.
} 
have more control over community affairs. As we saw in Table 6, by 1997 the problem of external border conflicts had been solved. The past history of cooperation also helps improve cooperative behavior, a regularity rationalized by Seabright (1993). The negative effect on the percentage of members who assisted assemblies in 1994 represents a saturation effect: those ejidos that were already at high levels of participation necessarily increase participation less. However, those that had internal rules in 1994 under state-led cooperation show a greater increase in cooperation. Hence, there was learning to cooperate that helped sustain higher levels of cooperation when the community acquired more self-determination rights.

We conclude that state-led cooperation was already importantly determined by endogenous behavior and that a new cooperative equilibrium under the new rules has not yet been reached, making community-led cooperation difficult to explain. Nevertheless, where conditions are favorable to cooperation (small size, less exit options, and a history of cooperative behavior), the level of participation further increased with liberalization of community behavior. Structural features of the communities such as size of membership play negatively, suggesting that many ejidos were created too large for successful endogenous cooperation. In our sample, $35 \%$ of the ejidos have more than 100 families and $14 \%$ more than 200. If, as we observed, 50 families is an optimum group size for effective cooperation, then only $34 \%$ of the ejidos qualify. If there are economies of scale in the provision of public goods and the management of CPR, optimum size may be larger. Yet, if moral hazards dominate in determining the outcomes of cooperation, reducing the size of the larger ejidos would seem to be a necessity in adjusting to the new rules of community behavior.

\section{Preservation or division of the commons and the role of cooperation}

The 1992 reforms opened the possibilities for ejidos to expand the area in individual plots by enclosing CPR lands, and to incorporate additional members, presumably from among the avencidados and posesionarios resident in the ejido, as full-rights ejidatarios. These possibilities have been highly unequally exercised across ejidos. We analyze in this section the determinants of these two decisions.

\subsection{Determinants of the decision to appropriate CPR resources}

The incentive for individual community members to press or not the assembly to enclose CPR land for individual use is based on a comparison of the profitability of using land individually relative to accessing land as a CPR. Land in plots is used for crops while land in CPR is used for pastures (say). Profitability of land in individual plots thus depends on the total factor productivity of resources in agriculture, on the relative price of agricultural versus livestock products, and on the size of the initial land allocations in private plots. The lower the initial allocations, the higher the marginal productivity of land in individual plots, and the greater the incentive to enclose more land. Profitability of land in CPR depends importantly on the quality of cooperation in managing these lands (McCarthy, de Janvry, and Sadoulet, 1998). If the quality of cooperation in the ejido is low, lands are overgrazed, and the profitability of animal husbandry is low. Hence, the lower the ability to cooperate, the greater the incentive to appropriate more land privately since the opportunity cost of land in CPR is low. Incentives to appropriate also depend on the quantity of CPR resources available per ejidatario, with greater availability lowering the marginal return from CPR land. Finally, appropriation can also be done for the purpose of settling new members as ejidatarios, usually family members who could not inherit land under the previous legislation. Hence, the greater the population pressure measured by the total ejido population per ejidatario, the greater the incentive to appropriate.

Econometric analysis of the determinants of appropriating CPR land in individual plots is reported in Table 9. Appropriation, cooperation, individual plot size, and CPR endowments per ejidatario in 1997 are all simultaneous. Hence, we use the levels of cooperation, individual plot size, and CPR endowments in 1994 as explanatory variables of the decision to appropriate land during the 1994-97 period. The data are truncated since a number of ejidos did not appropriate CPR land. To analyze these data, we use several specifications of the decision to appropriate: a probit of the binary choice to appropriate or not, an OLS and a LAD (median regression) on the share of CPR land appropriated among the ejidos that did appropriate, and a Tobit on the share of CPR appropriated across the whole sample. Each estimator has 
specific advantages and inconvenients. The Heckman probit-OLS approach allows to correct for selectivity bias, but has strong distributional assumptions and weak identification when the variables explaining the decisions to appropriate and how much to appropriate are the same. The LAD is distribution fee, consistent in the face of heteroscedasticity, and less sensitive to outliers than OLS because it minimizes the deviations around the median rather than the square of the deviations around the mean. It requires bootstrapping to calculate the distribution of estimated parameters and give less precise estimates. The Tobit makes strong distributional assumptions and also assumes that the determinants of the decision to divide and the quantity divided are the same. With no perfect estimator, results should consequently be read in terms of consistency across alternative specifications.

Results show that ejidos that are able to cooperate in managing CPR have less incentive to divide: those with formal rules for CPR use in 1994 and with more meetings per year in 1994 divided less frequently between 1994 and 1997 (probit) and divided a smaller share of the CPR (LAD and Tobit). Cooperation failure was thus an incentive to appropriate the commons. Smaller initial allocations of private plots create incentives to compensate by appropriating CPR. PROCEDE thus offered the communities a historical opportunity to enclose CPR in compensation for perceived insufficient size of individual plots. Enclosures were also more frequent (probit) when the ejido has greater endowments of CPR per ejidatario. A larger endowment, however, naturally implies that the percentage of the CPR that is appropriated declines very quickly with size (OLS and LAD), so that only in the very small ejidos did divisions occur. Both scarcity of land in individual plots and abundance of CPR land thus enter in the decision to appropriate land.

Communal ejidos had no individual plots in 1994, in general because agriculture is practiced using slash-and-burn on plots that are itinerant on communal land. These ejidos thus maintain land in common. However, soil fertility in individually cultivated plots is a common property resource (see Lopez, 1998), creating incentives to abuse extraction and hence pressures to divide if land is scarce. Pressure to divide is logically less among communal ejidos with larger CPR endowments per ejidatario since the commons problem on soil fertility is less severe. Communal ejidos apparently chose to divide (Tobit), but the share that is divided declines with size even more than for the other ejidos (in Table 9, the effect "CPR land per ejidatario if the ejido is communal" is additive to the effect "hectares of common land per ejidatario").

Population pressure is another important incentive to appropriate CPR. In all cases, it increases the percentage of the land that is being appropriated. Finally, the agroecological context matters. In tropical areas, agriculture is generally practiced in slash-and-burn, creating a common property problem for individual plots. This increases the incentive to appropriate the land in individual tenures.

Data in Table 10 indicate some of the consequences of appropriating the commons. Incorporation of new members and appropriation of the commons led to increased inequality. While inequality of individual plots remained the same in ejidos which did not divide CPR land (the ratio to the largest to the smallest plot changed from 7.2 to $8.5 \mathrm{ha}$ ), it increased sharply in the ejidos that did appropriate land, where it increased from 7.6 to 16.7 ha. Hence, this suggests that division of CPR lands was not used to compensate for inequalities. To the contrary, access to additional land apparently led to increasing disparities among members. Data in Table 8 also show that the incorporation of additional members had sharply contrasted implications for individual members whether there was or not division of CPR land. Division of CPR land allowed to incorporate new members while maintaining nearly unchanged the size of individual plots, as the area in individual plots declined by only $2.9 \%$. This, of course, was achieved at the cost of a sharp decline in the availability of CPR land per member that fell by $45 \%$. By contrast, ejidos that incorporated new members without dividing the commons incurred a loss of $26.8 \%$ in land in plots per member. Common land per member also fell as the number of members increased, but by only $33.9 \%$. Protecting the commons was thus done at the cost of less land under individual control per member.

\subsection{Determinants of the decision to incorporate new members}

The decisions to appropriate common land and to incorporate new members are jointly determined and consequently respond to the same determinants at the level of the reduced form. The determinants of incorporation are analyzed econometrically in Table 11. Incorporating new members implies giving them 
access to CPR, with negative externalities on current members. The higher the quality of cooperation, the better managed the CPR are, and hence the higher the opportunity cost of incorporating new members. For this reason, ejidos with higher quality cooperation are observed to incorporate less new members. Incorporation of new members is also more likely and represents a higher share of the existing membership if current members have higher individual land endowments and if the ejido has more common land. Larger CPR endowments make incorporation much easier since the opportunity cost on current members is lower. Communal ejidos did incorporate new members at an even higher pace, expectedly because community spirit is much higher in these ejidos. Population pressure plays, as expected, a role in the growth in membership (Tobit). Finally, older ejidos are more prone to incorporating additional members. The age of the ejido is positively correlated to population pressure since older ejidos have accumulated more descendants with demands for access to land on their own.

\section{Conclusions}

The ejido communities have extraordinary importance in Mexico for their control over extensive natural resources, their high share of irrigated agricultural land, the large fraction of rural population which they contain, and the presence of high levels of poverty. These communities did not evolve endogenously over a long historical period as witnessed in Africa, Asia, and other parts of Latin America such as Guatemala and Peru, but were the product of the state as part of the settlement of a bloody peasant-led revolution at the beginning of the century. They were consequently crafted for political control and to perform cooperatively under strong control of the state. Following the debt crisis and structural adjustment, the reforms of 1992 broke this equilibrium, devolving to the communities control over management of CPR and the delivery of local public goods, and allowing them to decide on individual appropriation or preservation of the commons. We analyzed in this paper how communities adjusted their behavior from state-led to community-led cooperation, and how they took advantage of the opportunity offered by the reforms to appropriate CPR as individual tenures and to incorporate new members with decisions-making rights.

Using data from surveys of ejido communities before participation to the land reform program (1994) and after (1997), we observed highly heterogeneous responses to the reforms across communities, with some improving levels of cooperation while it declined in others, and some appropriating CPR and incorporating new members, while others preferred to preserve the status quo in one or both of these options. We observed, in particular, that failure of ejidos to achieve high levels of cooperative behavior in the management of CPR created incentives toward greater private appropriation of common land. Hence, in the context of the reforms that gave communities opportunities to appropriate CPR in individual tenures, the low prevailing levels of cooperation in a majority of ejidos have contributed to rapid appropriation. This was undoubtedly rational given the prevailing levels of cooperation. However, maintaining extensive grazing and forestry resources in common property can have advantages if there are economies of scale and opportunities for geographical risk spreading, as is generally the case in extensive grazing and forestry operations as found in the ejido sector (see for example Wilson and Thompson, 1993; and Nugent and Sanchez, 1995). Preservation of these advantages of common property when they exist could be secured if communities were given proper assistance to enhance cooperation, particularly to adjust to the new policy context whereby cooperation must become community-led as opposed to state-led. We have seen that, given the historical context in which the land reform was designed, the ejido had not been organized to maximize the potential for successful cooperation in the management of community affairs, but principally as an instrument of political control and sate intervention in resource use. Hence, careful thinking needs be given about recrafting the ejido as an institution to optimize cooperative behavior. We found, for instance, that size beyond a threshold of 50 members weakens endogenous cooperation, suggesting that most ejidos were created too large to sustain effective cooperation under the new rules. Given the importance of the

natural and human resources located in the ejido sector, careful redesigning of the ejido communities for effective cooperation following devolution could thus have major productive, environmental, and welfare effects. 


\section{References}

Baitennmann, Helga. 1998. "The Article 27 Reforms and the Promise of Local Democratization in Central Veracruz", in Wayne Cornelius and David Myhre, editors, The Transformation of Rural Mexico, Center for U.S.-Mexican Studies, University of California at San Diego.

Baland, Jean-Marie, and Jean-Philippe Platteau. 1996. Halting Degradation of Natural Resources: Is There a Role for Rural Communities? Oxford University Press.

Cord, Louise, et al. 1998. Economic Adjustment and Institutional Reform: Mexico's Ejido Sector Responds. Washington D.C.:The World Bank, Latin America and Caribbean Region, Mexico Country Management Unit.

de Janvry, Alain, Gustavo Gordillo de Anda, and Elisabeth Sadoulet. 1997. Mexico's Second Agrarian Reform: Household and Community Responses. Center for U.S.-Mexico Studies, University of California, San Diego, La Jolla.

Goldring, Luin. 1998. "Having Your Cake and Eating It Too: Selective Appropriation of Ejido Reforms in Michoacán", in Wayne Cornelius and David Myhre, editors, The Transformation of Rural Mexico, Center for U.S.-Mexican Studies, University of California at San Diego.

Gordillo, Gustavo, Alain de Janvry, and Elisabeth Sadoulet. 1998. "Entre el control político y la eficiencia: evolución de los derechos de propriedad agraria en México”. CEPAL Review, 66: 149-166.

Hayami, Yujiro, and Jean-Philippe Platteau. 1997. "Resource Endowments and Agricultural Development: Africa vs. Asia”. CRED, University of Namur, Belgium.

Hirschman, Albert. 1970. Exit, Voice, and Loyalty, Cambridge, Massachusetts: Harvard University Press.

McCarthy, Nancy, Alain de Janvry, and Elisabeth Sadoulet. 1998. "Land Allocation Under Dual Individual-Collective Use in Mexico”, Journal of Development Economics, 56(2) 239-264.

Lopez, Ramón. 1998. "The Tragedy of the Commons in Côte d'Ivoire Agriculture: Empirical Evidence and Implications for Evaluating Trade Policies", The World Bank Economic Review, 12(1): 105-31.

Nugent, Jeffrey, and Nicolas Sanchez. 1995. "The Local Variability of Rainfall and Tribal Institutions: The Case of Sudan", Economics Department, University of Southern California, Los Angeles, California.

Ostrom, Elinor. 1992. Governing the Commons: The Evolution of Institutions for Collective Action. New York: Cambridge University Press.

Scott, James. 1976. The Moral Economy of the Peasant: Rebellion and Subsistence in Southeast Asia. New haven: Yale University Press.

Seabright, Paul. 1993. "Managing the Local Commons: Theoretical Issues in Incentive Design”, J. of Econ. Perspectives 7 (Fall): 113-34.

Wilson, Paul, and Gary Thompson. 1993. "Common Property and Uncertainty: Compensating Coalitions by Mexico's Pastoral Ejidatarios”. Economic Development and Cultural Change, (41):299-318. 
Table 1. Access to land in the ejido, 1997

\begin{tabular}{|c|c|c|c|c|c|c|c|}
\hline \multirow[b]{2}{*}{ Forms of tenure } & \multicolumn{3}{|c|}{ Land distribution in the sample } & \multicolumn{4}{|c|}{$\begin{array}{l}\text { Land in ejidos that have } \\
\text { the corresponding form of tenure }\end{array}$} \\
\hline & $\begin{array}{l}\text { Number } \\
\text { of ejidos }\end{array}$ & $\begin{array}{c}\text { Total area } \\
\text { per ejido (ha) }\end{array}$ & $\begin{array}{l}\% \text { of the } \\
\text { land }\end{array}$ & $\begin{array}{l}\text { Number } \\
\text { of ejidos }\end{array}$ & $\begin{array}{l}\% \text { of the } \\
\text { land }\end{array}$ & Land per $m$ & er (ha) \\
\hline Individual plots in usufruct & 286 & 965 & 28.4 & 252 & 58.0 & & \\
\hline Common property resources (CPR) & 286 & 2380 & 69.9 & 226 & 76.9 & $\begin{array}{l}\text { Individual } \\
\text { CPR }\end{array}$ & $\begin{array}{l}11.3 \\
35.2\end{array}$ \\
\hline Urban zones & 286 & 46 & 1.4 & 274 & 3.3 & & \\
\hline Other & 286 & 12 & 0.4 & & & & \\
\hline Total & 286 & 3403 & 100.0 & & & & \\
\hline
\end{tabular}

Table 2. Importance of common property resources (CPR) across ejidos, 1997

\begin{tabular}{lcc} 
Share of land in CPR & $\begin{array}{c}\text { Number } \\
\text { of ejidos }\end{array}$ & $\begin{array}{c}\% \text { in the } \\
\text { sample }\end{array}$ \\
\hline None & 60 & 21.0 \\
0 to $10 \%$ & 34 & 11.9 \\
10 to $50 \%$ & 57 & 19.9 \\
50 to $90 \%$ & 71 & 24.8 \\
$>90 \%$ & 64 & 22.4 \\
Total & 286 & 100.0 \\
\hline
\end{tabular}

Table 3. Use of CPR land in ejidos, 1997

\begin{tabular}{lcccc} 
Types of use & $\begin{array}{c}\text { Number } \\
\text { of ejidos }\end{array}$ & $\begin{array}{c}\text { Share of ejidos } \\
\%\end{array}$ & $\begin{array}{c}\text { Share of land } \\
\%\end{array}$ & $\begin{array}{c}\text { Area } \\
\text { ha }\end{array}$ \\
\hline CPR pastures & 173 & 77.6 & 51.6 & 1993 \\
CPR forests & 112 & 50.2 & 36.5 & 2201 \\
Individual cultivation of CPR land & 57 & 25.6 & 5.6 & 658 \\
Collective cultivation of CPR land & 13 & 5.8 & 0.3 & 146 \\
Other uses & 42 & 18.8 & 6.6 & 1060 \\
Total CPR land & 223 & & 100 & 3916 \\
\hline
\end{tabular}


Table 4. Population pressure for access to land in the ejido

\begin{tabular}{|c|c|c|c|}
\hline Categories of households & $\begin{array}{l}\text { Number of } \\
\text { households }\end{array}$ & $\begin{array}{c}\text { Distribution } \\
\text { of households } \\
\% \\
\end{array}$ & $\begin{array}{c}\text { Other } \\
\text { statistics }\end{array}$ \\
\hline \multicolumn{4}{|l|}{ All ejidos (286 ejidos) } \\
\hline Ejidatarios & 103 & 59.9 & \\
\hline Posesionarios & 18 & 10.5 & \\
\hline Avencidados & 51 & 29.7 & \\
\hline Posesionarios/ejidatario & & & 0.2 \\
\hline Avencidados/ejidatario & & & 0.5 \\
\hline \multicolumn{4}{|l|}{ Ejidos with posesionarios (130 ejidos) } \\
\hline Posesionarios & 38 & & \\
\hline Posesionarios/ejidatario & & & 0.4 \\
\hline Area cultivated per posesionario (ha) & & & 5.0 \\
\hline \multicolumn{4}{|l|}{ Ejidos with avencidados (189 ejidos) } \\
\hline Avencidados & 76 & & \\
\hline Avencidados/ejidatario & & & 1.0 \\
\hline
\end{tabular}

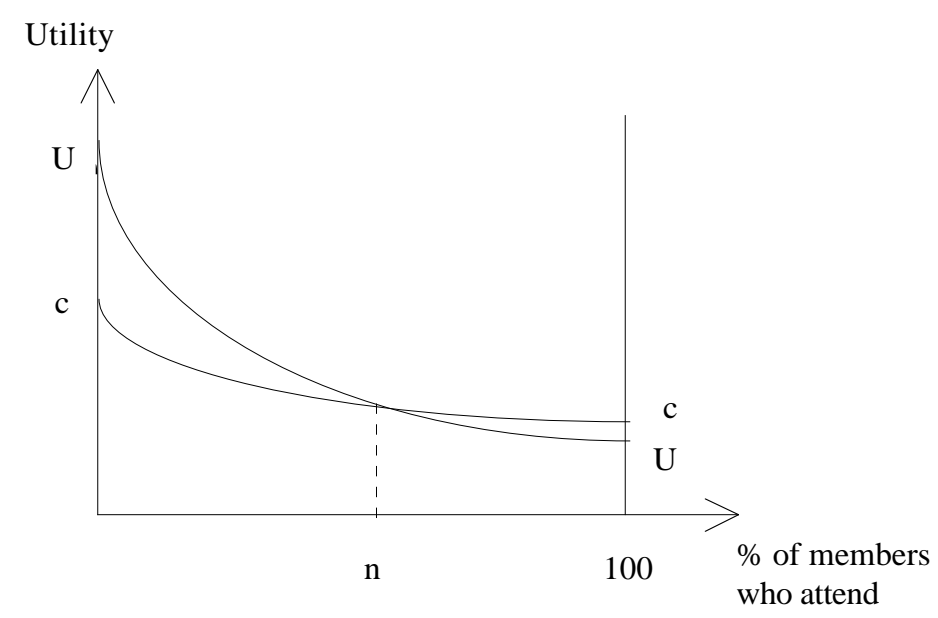

Figure 1. Equilibrium attendance to assemblies 
Table 5. Indicators of cooperation at the ejido level, 1997

Percentage

I. Symptoms of quality of governance and cooperation in ejidos (286 ejido-level observations)

Ejido has internal rules (yes/no)

Rules have been actualized as required by law (yes/no)

$\begin{array}{ll}\text { Rules are registered with government (yes/no) } & 68\end{array}$

$\begin{array}{ll}\text { Quorum is achieved at first call of assembly (yes/no) } & 73\end{array}$

Percentage of ejidatarios who come to assembly $\quad 65$

Ejido keeps registry of agreements (yes/no) $\quad 85$

2. Cooperation in pasture management (159 ejidos with common property pastures)

Existence of rules on provision

$\begin{array}{ll}\text { Ejidatarios who use pastures must pay fees (yes/no) } & 15\end{array}$

Ejidatarios must participate to repair of fences (yes/no) $\quad 42$

Ejidatarios must participate to weed control (yes/no) 14

Ejidatarios must participate to surveillance of ejido borders (yes/no) 39

Existence of rules on extraction

Animals are rotated among fields (yes/no) 12

Ejido has rules limiting the number of animals per member (yes/no) 13

Ejido has problems of intrusion of outsiders into pastures (yes/no) 23

Symptoms of quality cooperation

Pastures have had an increase in the presence of weeds since 1994 (yes/no) 26

Pastures have had an increase in erosion gullies since 1994 (yes/no) 27

3. Cooperation in forest management (106 ejidos with common property forests)

Existence of rules on provision

Ejido had reforestation projects in the last three years (yes/no)

Existence of rules on extraction

Ejido imposes individual limits on timber extraction by ejidatarios (yes/no) 31

$\begin{array}{ll}\text { Ejido imposes fines or punishments if limits are not respected (yes/no) } & 70\end{array}$

Ejido allows avencidados and posesionarios to extract timber (yes/no) 58

Symptoms of quality cooperation

Percentage of ejidatarios who respect limits on timber extraction (\%) 85

Illegal extraction is observed (yes/no)

4. Cooperation in the provision of public goods: Maintenance or construction of infrastructure (1634 individual ejidatario household observations)

Symptoms of cooperation: participation to maintenance activity when activity exists (yes/no)

Roads

Irrigation infrastructure $\quad 24$

Public lighting

$\begin{array}{ll}\text { School } & 57\end{array}$

Health center $\quad 32$

$\begin{array}{lr}\text { Social center } & 25\end{array}$

Animal corrals $\quad 8$

\begin{tabular}{ll} 
Other activities & 92 \\
\hline
\end{tabular}

$\begin{array}{ll}\text { Total } & 79\end{array}$ 
Table 6. Determinants of cooperation in 1994 and 1997: assistance to assemblies Robust Ordinary Least Squares

1994

1997

Coefficient t-statistic Coefficient t-statistic

Expected benefits from cooperation

Market integration (distance to nearest population center)

Quantity of resource: ha CPR/ejidatario

Variable costs of enforcing cooperation

Group characteristics

Group size: Number of ejidatarios

Group size: Number of avecindados

Group heterogeneity : Plot size disparity ${ }^{1}$

Exit option (size of migration network ${ }^{2}$ )

Social cohesion

Ejido has indigenous majority ${ }^{3}+$

Age of the ejido (years since foundation)

Ejido has external border conflicts +

Facilitators of cooperation

Ejido has sources of income $e^{4}+$

Goodness-of-fit: R2

$-0.002$

$-2.71$

0.0004

1.90

0.00009

0.12

(1)

$-0.001$

$-5.28$

$-0.00008$

$-2.25$

$-0.008$

$-1.63$

$-0.42$

$-1.09$

0.0003

0.98

Number of observations ${ }^{5}$

+ Dummy variable

${ }^{1}$ Ratio of largest to smallest individual plot in the ejido.

${ }^{2}$ Migration network $=$ percentage of adults with migration experience in the ejido.

${ }^{3}$ Indigenous $=$ individual who speaks an indigenous language.

${ }^{4}$ Ejido earns income from common property resources.

${ }^{5}$ The number of observations differs in 1994 and 1997 due to missing data in 1994. 
Table 7. Effect of group size on the percentage of members who assist to assemblies (Partial results from robust ordinary least squares regression)

\begin{tabular}{ccccc}
\hline $\begin{array}{c}\text { Community size: } \\
\text { number of } \\
\text { ejidatarios }\end{array}$ & Coefficient & t-statistic & $\begin{array}{c}\text { Cumulative effect } \\
\text { (Slope) }\end{array}$ & t-statistic \\
\hline 1 to 50 & -0.06 & -0.28 & -0.06 & -0.28 \\
50 to 75 & -0.74 & -1.81 & -0.80 & -3.78 \\
more than 75 & 0.73 & 3.34 & -0.07 & -3.45 \\
\hline
\end{tabular}

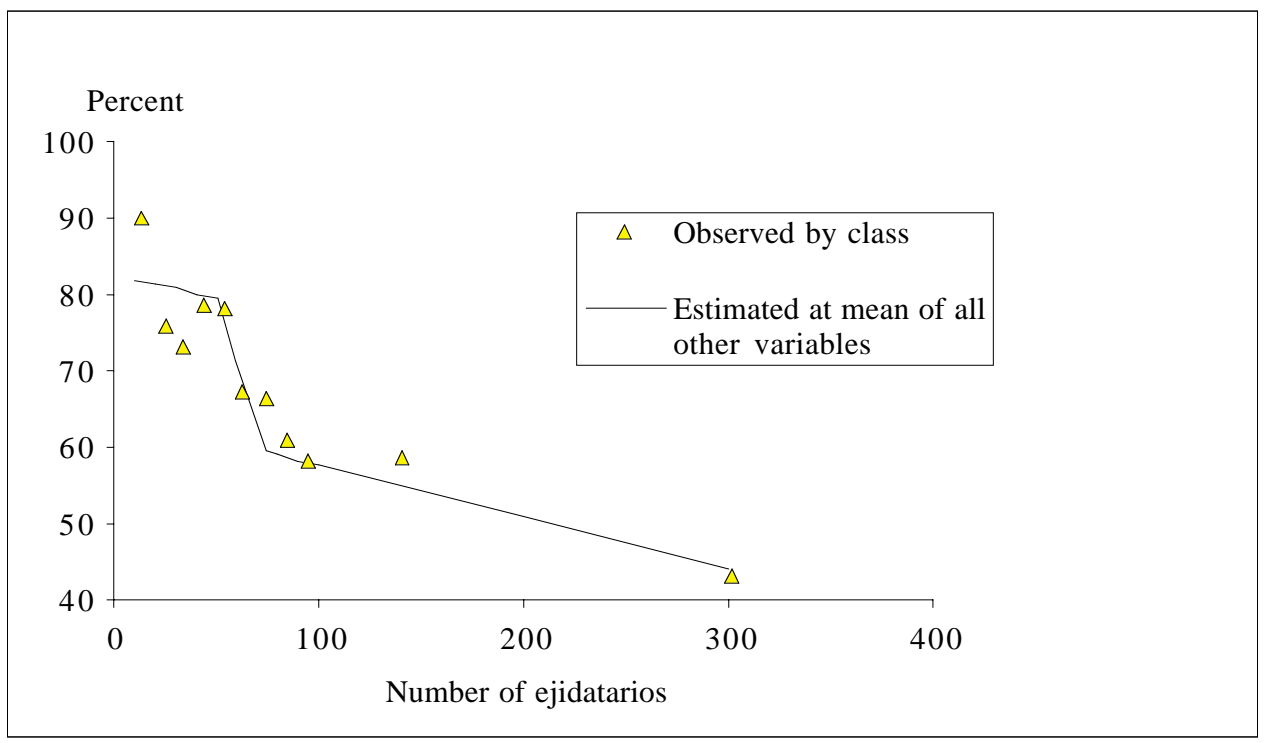

Figure 2. Cooperation and community size:

Percentage of members who assist to assemblies and number of ejidatarios 
Table 8. Determinants of change in cooperation between 1994 and 1997: change in assistance to assemblies

Robust Ordinary Least Squares

Change 1994-97

Coefficient t-statistic

\begin{tabular}{|c|c|c|}
\hline \multicolumn{3}{|l|}{ Expected benefits from cooperation } \\
\hline Market integration (distance to nearest population center) & 0.0009 & 1.50 \\
\hline Quantity of resource: ha CPR/ejidatario & 0.000 & 0.01 \\
\hline \multicolumn{3}{|l|}{$\begin{array}{l}\text { Variable costs of enforcing cooperation } \\
\text { Group characteristics }\end{array}$} \\
\hline Group size: Number of ejidatarios & -0.001 & -5.15 \\
\hline Group size: Number of avecindados & 0.000 & 0.17 \\
\hline Group heterogeneity : Plot size disparity ${ }^{1}$ & 0.007 & 1.42 \\
\hline Exit option (size of migration network ${ }^{2}$ ) & -1.22 & -3.23 \\
\hline \multicolumn{3}{|l|}{ Social cohesion } \\
\hline Ejido has indigenous majority ${ }^{3}+$ & 0.03 & 0.68 \\
\hline Age of the ejido (years since foundation) & -0.0007 & -0.90 \\
\hline Ejido has external border conflicts + & 0.052 & 1.74 \\
\hline \multicolumn{3}{|l|}{ Facilitators of cooperation } \\
\hline Ejido has sources of income $e^{4}+$ & 0.003 & 0.09 \\
\hline \multicolumn{3}{|l|}{ Cooperation in 1994} \\
\hline$\%$ of members who assist to assemblies + & -0.53 & -6.72 \\
\hline Quorum achieved on first call + & 0.025 & 0.67 \\
\hline Frequency of assembly meetings + & 0.021 & 2.27 \\
\hline Ejido has internal rules + & 0.051 & 1.72 \\
\hline Goodness-of-fit: R2 & 0.37 & \\
\hline Number of observations & 176 & \\
\hline
\end{tabular}

+ Dummy variable

${ }^{1}$ Ratio of largest to smallest individual plot in the ejido.

${ }^{2}$ Migration network $=$ percentage of adults with migration experience in the ejido.

${ }^{3}$ Indigenous $=$ individual who speaks an indigenous language.

${ }^{4}$ Ejido earns income from common property resources. 
Table 9. Appropriation of common property land, 1994-97

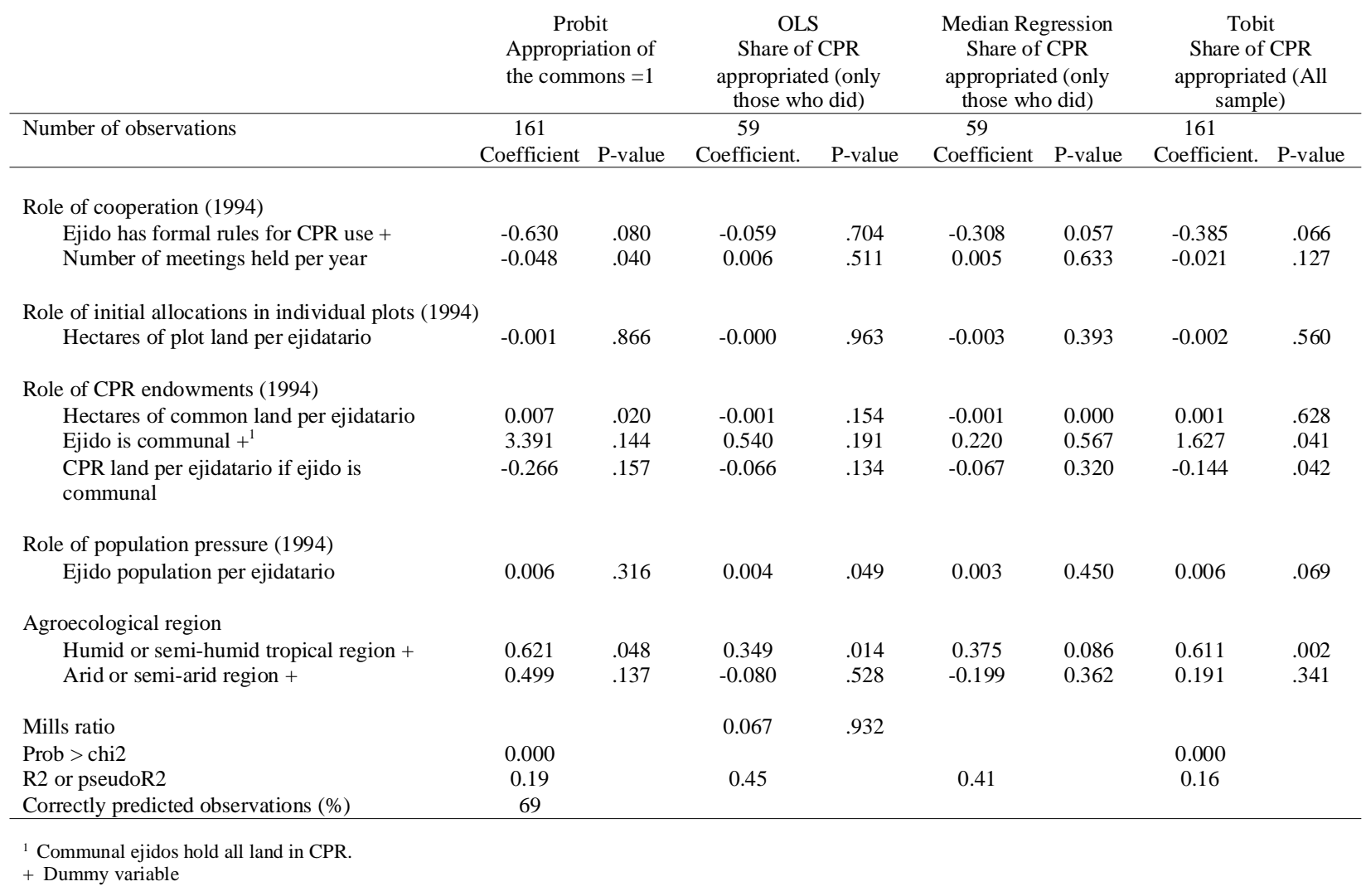

Table 10. Consequences of individual appropriation of CPR land

\begin{tabular}{ccc}
$\begin{array}{c}\text { Ejidos which had CPR } \\
\text { and did not divide }\end{array}$ & $\begin{array}{c}\text { Ejidos which had CPR } \\
\text { and divided } \\
\text { partially or totally }\end{array}$ & $\begin{array}{c}\text { Test of } \\
\text { difference }\end{array}$ \\
\hline
\end{tabular}

Impact on inequality of land in plots across ejidatarios: ratio of largest to smallest individual plot

$\begin{array}{lrrr}1994 & 7.2 & 7.6 & \\ 1997 & 8.5 & 16.7 & *\end{array}$

Impact of incorporation of new members on access to land (among ejidos that increased membership)

1994 individual plot land per member (ha) $\quad 14.9 \quad 17.3$

1997 individual plot land per member (ha) $\quad 10.9 \quad 16.8$

\% change $94-97 \quad-26.8 \quad-2.9$

1994 CPR land per member (ha) $\quad 32.7 \quad 57.6$

1997 CPR land per member (ha) $\quad 21.6 \quad 31.6$

\% change 94-97 $\quad-33.9 \quad-45.1$


Table 11. Incorporation of new members in the ejido, 1994-97

\begin{tabular}{|c|c|c|c|c|c|c|c|c|}
\hline \multirow[b]{2}{*}{ Number of observations } & \multicolumn{2}{|c|}{$\begin{array}{l}\text { Probit } \\
\text { Incorporated members } \\
=1\end{array}$} & \multicolumn{2}{|c|}{$\begin{array}{l}\text { OLS } \\
\% \text { increase in members } \\
\text { (only those who did) }\end{array}$} & \multicolumn{2}{|c|}{$\begin{array}{l}\text { Median regression } \\
\% \text { increase in members } \\
\text { (only those who did) }\end{array}$} & \multicolumn{2}{|c|}{$\begin{array}{c}\text { Tobit } \\
\% \text { increase in members } \\
\text { (All sample) }\end{array}$} \\
\hline & $\begin{array}{c}161 \\
\text { Coefficient } \\
\end{array}$ & $\mathrm{P}>|\mathrm{z}|$ & $\begin{array}{c}67 \\
\text { Coefficient } \\
\end{array}$ & $\mathrm{P}>|\mathrm{z}|$ & $\begin{array}{c}67 \\
\text { Coefficient } \\
\end{array}$ & $\mathrm{P}>|\mathrm{z}|$ & $\begin{array}{c}161 \\
\text { Coefficient } \\
\end{array}$ & $\mathrm{P}>|\mathrm{z}|$ \\
\hline Role of cooperation (1994) & & & & & & & & \\
\hline $\begin{array}{l}\text { Ejido has formal rules for CPR use + } \\
\text { Number of meetings held per year }\end{array}$ & $\begin{array}{l}-0.299 \\
-0.039\end{array}$ & $\begin{array}{l}0.315 \\
0.094\end{array}$ & $\begin{array}{l}-0.675 \\
-0.039\end{array}$ & .066 & $\begin{array}{l}-0.219 \\
-0.013\end{array}$ & $\begin{array}{l}.268 \\
.281\end{array}$ & $\begin{array}{l}-0.50 \\
-0.02\end{array}$ & $\begin{array}{l}0.080 \\
0.170\end{array}$ \\
\hline $\begin{array}{l}\text { Role of initial allocations in individual plots }(1994) \\
\text { Hectares of plot land per ejidatario } \\
\text { Average number of intra-ejido land transactions } \\
1992-97\end{array}$ & $\begin{array}{l}0.019 \\
3.990\end{array}$ & $\begin{array}{l}0.061 \\
0.030\end{array}$ & $\begin{array}{r}0.006 \\
-0.091\end{array}$ & $\begin{array}{l}.341 \\
.903\end{array}$ & $\begin{array}{l}0.002 \\
0.449\end{array}$ & $\begin{array}{l}.863 \\
.531\end{array}$ & $\begin{array}{l}0.015 \\
1.287\end{array}$ & $\begin{array}{l}0.024 \\
0.072\end{array}$ \\
\hline $\begin{array}{l}\text { Role of CPR endowments (1994) } \\
\text { Hectares of common property land per ejidatario } \\
\text { Ejido is communal + } \\
\text { CPR land per ejidatario if ejido is communal }\end{array}$ & $\begin{array}{l}0.005 \\
0.939 \\
-0.006\end{array}$ & $\begin{array}{l}0.050 \\
0.010 \\
0.062\end{array}$ & $\begin{array}{c}0.002 \\
-0.103 \\
0.000\end{array}$ & $\begin{array}{l}.196 \\
.765 \\
.856\end{array}$ & $\begin{array}{c}0.002 \\
-0.122 \\
0.001\end{array}$ & $\begin{array}{l}.432 \\
.777 \\
.898\end{array}$ & $\begin{array}{r}0.005 \\
0.622 \\
-0.004\end{array}$ & $\begin{array}{l}0.004 \\
0.005 \\
0.071\end{array}$ \\
\hline $\begin{array}{l}\text { Role of population pressure (1994) } \\
\text { Avecindado households per ejidatario } \\
\text { Years since ejido foundation }\end{array}$ & $\begin{array}{l}0.017 \\
0.007\end{array}$ & $\begin{array}{l}0.333 \\
0.258\end{array}$ & $\begin{array}{l}0.015 \\
0.006\end{array}$ & $\begin{array}{l}.288 \\
.325\end{array}$ & $\begin{array}{c}0.016 \\
-0.000\end{array}$ & $\begin{array}{l}.398 \\
.977\end{array}$ & $\begin{array}{l}0.029 \\
0.100\end{array}$ & $\begin{array}{l}0.049 \\
0.066\end{array}$ \\
\hline $\begin{array}{l}\text { Agroecological region } \\
\text { Humid or semi-humid tropical region }+ \\
\text { Arid or semi-arid region }+\end{array}$ & $\begin{array}{l}0.349 \\
0.129\end{array}$ & $\begin{array}{l}0.210 \\
0.679\end{array}$ & $\begin{array}{l}-0.448 \\
-0.477\end{array}$ & $\begin{array}{l}.128 \\
.124\end{array}$ & $\begin{array}{l}-0.159 \\
-0.179\end{array}$ & $\begin{array}{l}.574 \\
.428\end{array}$ & $\begin{array}{c}0.045 \\
-0.236\end{array}$ & $\begin{array}{l}0.858 \\
0.406\end{array}$ \\
\hline $\begin{array}{l}\text { Mills ratio } \\
\text { R2 or pseudo R2 } \\
\text { Correctly predicted observations (\%) }\end{array}$ & $\begin{array}{c}0.12 \\
67\end{array}$ & & $\begin{array}{c}-0.131 \\
0.17\end{array}$ & .803 & 0.12 & & 0.08 & \\
\hline
\end{tabular}

+ Dummy variable. 